\title{
Academic Achievement in Algebra of the Public High School Students in the New Normal
}

\author{
Diana B. Rodrigo ${ }^{1}$ and Alfredo D. Alave ${ }^{2}$ \\ 1,2University of Negros Occidental-Recoletos \\ Bacolod City, Philippines
}

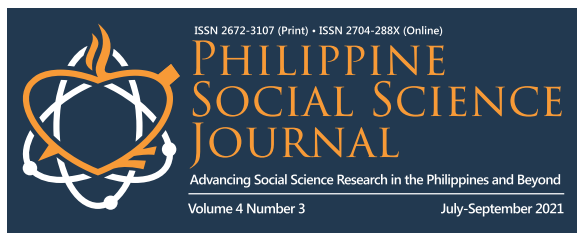

Submitted: 18 July 2021

Revised: 13 October 2021

Accepted: 25 October 2021

Mathematic education

Academic achievement

Algebra

Public high school students

Descriptive-correlational

Philippines

\section{Article history:}

\section{Keywords:}

ABSTRACT. This study describes the academic achievement level in Algebra of the public secondary school students in the new normal as a whole and when grouped according to sex and parent's highest educational attainment. Utilizing descriptive-comparative and correlational designs, the academic achievement level, significant differences and relationships among the variables, and the perceived learning difficulties in Quadratic Functions were determined using mean, Mann-Whitney, Kruskal Wallis, Chi-square test of association, Spearman rank correlation, and frequency and percentage distribution. Results showed that the academic achievement level was low; no significant difference and relationship between sex and academic achievement level; there was a significant difference and relationship between parent's highest educational attainment and achievement level, and students' top difficulty is transforming quadratic functions into the form $f(x)=\left[a(x-h)^{\wedge} 2\right]+k$. Therefore, Algebra teachers, school heads, and parents should take necessary interventions to address the problem.

\subsection{Introduction}

The occurrence of the pandemic is unprecedented, and it had resulted in school closures before the official end of the school year 2019-2020, which then proceeded into $37 \%$ to $50 \%$ only of the learning gains in mathematics when students would be back in the next academic year (Kuhfeld et al., 2020). According to Northwest Evaluation Association, students could lose more ground in math than in reading. They would learn only half or up to full-year less math in 2020-2021 compared to what they have learned during a typical year (Sawchuk, 2021).

Consequently, it was revealed that there will be more likely a drop in the math performance of the secondary school students in the national examination if ever the pandemic is not contained in the earliest time possible considering the abruptly disrupted school calendar brought about by the premature school closure (Sintema, 2020). Students' interest in learning math, specific to the context of algebra (even before the pandemic), already declines as they reach adolescence since they find concepts in the latter to be hardly applicable in the real world (Galindo \& Newton, 2017). With what the pandemic has delivered, instructions will be critical as ever. There will be varying degrees of learning loss (Shafer, 2020).

Algebra learning standing had already become a struggle. Like in Malaysia, even 4-5 hours per week are allotted to master the subject, yet Trends in Mathematics and Science Study (TIMSS) reported that Malaysian learners' performance in algebra lags far behind any other country. They are the worst performers in mathematics in the 2012 Program for International Student Assessment or PISA (Lim, 2016). More so, in the 2007 and 2011 TIMSS results, international ratings in algebra performance have dropped from 49 to 36 and from 42 to 38 in the respective years; hence, the student's ability in algebra is relatively low (Pramesti \& Retnawati, 2019).

Specific to the Philippine setting, PISA 2018 findings also revealed that 15-year-old representative Filipinos had ranked 78th in mathematics out of 80 countries. Indeed, Filipinos' math performance is deteriorating (Silk et al., 2017). This long-standing problem is more burdened by the difficulties posed by the pandemic, which boils down to the possibility that school institutions may no longer effectively impart the literacy and numeracy skills required of the learners (Teodoro, 2020). Restrictions that the new normal imposed have led to a major overhaul of the educational systems globally, most importantly, in the Philippines (Mateo, 2020), and coronavirus will leave many students academically behind with only $44 \%$ of learning gains in mathematics, with a more widened achievement gap (Terada, 2020). but not in any way that suggests the licensor endorses you or your use. You may not use the material for commercial purposes.
} 
Correspondingly, the Department of Education has implemented DepEd Order No. 012 Series of 2020 or the Adoption of the Basic Education Learning Continuity Plan for School Year 2020-2021 in the light of the Coronavirus Disease 2019 (COVID-19) Public Health Emergency, which provides access to education through necessary and available platforms (either online or offline). Nonetheless, the greater challenge is left to those who can hardly comprehend content through distance education (Mateo, 2020). The pandemic has brought about varied concerns like cognitive work overload in some local schools for learners and teachers (Malindog-Uy, 2020). For instance, in implementing a learning modality among the selected educational institutions in Region IV-A amidst health crisis, learners exclaim that distance learning is not suitable and applicable for mathematics because comprehending it through alternative platforms is difficult; hence a decline in math performance among the students is anticipated (Reyes-Chua et al., 2020).

However, there is still little to no data available affirming the decline of the actual math achievement of the students, particularly in algebra during COVID-19, because most literature existing on the depreciation of the math achievement level of the learners are only mere projections (Kuhfeld et al., 2020; Sawchuk, 2021; Di Pietro et al., 2020; Dorn et al., 2020; Sintema, 2020; Majumdar, 2020) hence, a gap in the literature is established.

Thus, this study primarily intended to investigate the actual academic achievement level in the first quarter algebra in the new normal of the public high school Grade 9 students, when they are taken as a whole and when grouped according to sex and parent's highest educational attainment. This also aimed to determine their learning difficulties in quadratic functions. Moreover, the paper also sought to establish a possible difference and relationship between the respondents' demographic profile and their academic achievement level.

\subsection{Framework of the Study}

Theoretical assumptions in this research are generally anchored on two different theories: the Entity Theory in C. Dweck's Implicit Theories and the Sociocultural Theory by Lev Vygotsky.

In the Entity Theory in Dweck's Implicit Theories, an individual's intelligence and abilities are believed to be relatively fixed and stable (Costa \& Faria, 2018). Therefore, those who tend to grasp the idea of entity theory tend to associate their failures with their own unchangeable and stable abilities. Hence, their attributional style leads to lesser self-worth and motivation because they believe that they can no longer change their attributes (Heller et al., 2001).

There is a traditional math-gender stereotype suggesting that males have a greater tendency to enjoy and succeed in mathematics while females are more likely to enjoy and succeed in the fields of language art courses (Morrissey et al., 2019). Several studies from the past 20 years have indicated that males outperform females in mathematics (Frenzel, 2008). According to a new study of researchers from the University of Washington, children express that mathematics is for boys. Hence, the latter identified themselves with the subject, the reason why girls usually end up picking any non-math-related careers (McElroy, 2011). As a result, almost $90 \%$ and $80 \%$ of academic and non-academic math-related positions in the US are held by males (Anglin et al., 2008, cited in Vijayakumaran, 2017).

Likewise, Mittelberg et al. (2011) mentioned that a Druze teacher believed that females must have affirmative action to overcome such gender biases in mathematics in favor of males. The findings of the latter researchers have also affirmed that gender stereotypes and expectations impact the student's classroom experiences and mathematical achievements. Indeed, stereotype threat compromises the learners' working memory capacity in mathematics (Maloney et al., 2013) because negative perceptions about a social group may result in lower performance of members from that social group, especially if there is a fear that they would conform to such beliefs (Chu, 2010).

On the other hand, Vygotsky's sociocultural theory emphasizes the relationship between the learning acquisition of human beings and their environment (Tekin, 2011). The construct of Zone of Proximal Development (ZPD) was introduced in the context which asserts that for a child to master his "proximal" skills and to be able to work independently, he needs the assistance of a more knowledgeable adult (Cherry, 2020), who could be in the person of a teacher or a parent (Kurt, 2020).

Several studies have existed affirming parental education's direct effect on mathematics learning through parent's ability to help with a child's homework (Tabaeian, 2016; Dettmers et al., 2019). The responsibility to socialize and educate children is a shared obligation between parents and school; hence, parental involvement is crucial to the students' academic success (Cole, 2017). Parental involvement is the parents' direct participation in their children's educational experience 
by fulfilling their duties in making sure that they are well assisted in the learning process (Clinton $\&$ Hatie, 2013, cited in Ntekane, 2018).

As for the extent of parental involvement, several studies (Li \& Qui, 2018; Lam \& Ducreux, 2013; Bæck, 2010; Jafarov, 2015) revealed that it is greatly impacted by the parent's level of academic attainment in a sense that parents/guardians who have experienced a more formal education are more directly involved in child's schooling than the less educated parents/guardians.

Specific to mathematics, Kodippili (2011) affirmed that parent's education level is significantly affecting student's math achievement, where for both average students, for instance, one whose parent had reached post-secondary schooling would score better in math assessments as compared to the other whose parent is only until secondary education level.

In the context of algebra, Cordova and Tan (2018) examined the students' performance in private high schools within Bukidnon, Philippines, in relation to their parent's educational attainment. They later proved the assumption that the higher the parent's educational attainment is, the higher also is the parental involvement, hence the more the parent can guide his/her child in learning the subject.

\subsection{Methods}

This study utilized the descriptive-comparative research design to describe and compare the level of academic achievement of the Grade 9 students in the first quarter algebra during the new normal as a whole and according to their demographic profiles, such as sex and parent's highest educational attainment. It also determined their learning difficulties, particularly in quadratic functions (Aggarwal \& Ranganathan, 2019). Also, the correlational research design was employed to seek if the respondents' performance in the assessment is significantly linked with their demographic profiles (Akinlua, 2019). The respondents in this study were the 270 Grade 9 students of a public school in Murcia, Negros Occidental, during the first quarter of the academic year 2020-2021, chosen through stratified random sampling. Meanwhile, the utilization of the respondents was based on the assumption that $9^{\text {th }}$ graders become the most appropriate subject of the research on the academic achievement level because their level becomes the determiner if they would advance in school or not (Willens, 2013).

The data were gathered using a 3-part researcher-made questionnaire. The first part consists of the respondents' demographic information; the second part is a researcher-made 40 -item test questionnaire on first-quarter algebra, and the third part is a checklist on students' identified learning difficulties in quadratic functions. The test questionnaire was aligned to the DepEd competencies in Grade 9 Algebra first quarter plotted on the DepEd MELC 2020 and was validated by five public secondary school teachers through the Good and Scates validity rating scale, which garnered a validity score of 4.7. Right after which, the item analysis and reliability test followed and yielded a Kuder-Richardson 20 (KR 20) of 0.933 . The mean scores of the respondents on the data gathered were verbally described according to the following scale of interpretation:

Table 1. Interpretative scale for the level of academic achievement in Algebra

\begin{tabular}{lll}
\hline Mean Score & Verbal Description & Verbal Interpretation \\
\hline $0.00-8.00$ & Very low & Did not meet expectations \\
$8.01-16.00$ & Low & Fairly satisfactory \\
$16.01-24.00$ & Average & satisfactory \\
$24.01-32.00$ & High & Very satisfactory \\
$32.01-40.00$ & Very high & Outstanding \\
\hline
\end{tabular}

Mean, frequency, and percentage were utilized to describe the students' academic achievement levels and determine their learning difficulties. Meanwhile, Mann-Whitney and Kruskal Wallis were used in comparing the respondents' achievement levels when grouped according to sex and parent's highest educational attainment. On the other hand, the Chi-square test of association and Spearman rank correlation were used to find significant relationships between the demographics of the respondents and their algebra academic achievement level. 


\subsection{Results and Discussion}

\section{Level of academic achievement in Algebra}

Table 2 shows the level of academic achievement in algebra, specifically in the area of quadratic functions, as a whole and when grouped according to sex and parent's highest educational attainment. As a whole $(M=13.80, S D=4.59)$, the respondents' level of academic achievement in algebra during the first quarter of the AY 2020-2021 is "low." When grouped according to sex and parent's highest educational attainment, the level of academic achievement of males $(M=13.22$, $S D=4.47)$, females $(M=14.27, S D=4.64)$. Meanwhile, students with college-level parents obtained an "average" achievement level.

Table 2. Level of Academic Achievement in Algebra (Quadratic Functions)

\begin{tabular}{lccc}
\hline Variable & M & SD & Interpretation \\
\hline Sex & & & \\
$\quad$ Male & 13.22 & 4.47 & Low \\
$\quad$ Female & 14.27 & 4.64 & Low \\
Parent's Highest Educational Attainment & & & \\
$\quad$ Elementary & 13.30 & 4.75 & Low \\
$\quad$ High School & 13.58 & 4.26 & Low \\
College & 16.09 & 5.30 & Average \\
As a Whole & 13.80 & 4.59 & Low \\
\hline
\end{tabular}

Results further reveal that subgroups of males, females, and those who have elementary or high school level parents have a "low" mean score in the topics of illustrating Quadratic Equation $(\mathrm{QE})$, solving $\mathrm{QE}$ by completing the square and by using the quadratic formula, characterizing the roots of a $\mathrm{QE}$, solving equations transformable into $\mathrm{QE}$, and finally, transforming $\mathrm{QE}$ into the form, . In contrast, their mean scores on solving $\mathrm{QE}$ by factoring and problem solving involving $\mathrm{QE}$ is on the "average" level. On the other hand, respondents with college-level parent/s $(M=16.09, S D=5.30)$ have an "average" level of academic achievement in algebra. They also had an "average" mean score in the topics of illustrating $\mathrm{QE}$, solving QE by factoring, problem-solving, and transforming $\mathrm{QE}$ into the form , while they revealed a "low" level in the topics of solving QE by completing the square and by using the quadratic formula, characterizing the roots of a $\mathrm{QE}$, and solving equations transformable into QE.

The new normal setting further intensified the "substantial" math losses of the students during the pandemic as brought about by the COVID-19 disruptions, including delayed school openings, lack of universal access to technology, shifting to distance learning, and the "compromised" student engagement, and the changes in instructional format (Schaffhauser, 2020). It was found out that even though learning alternatives in the form of remote learning were devised, students when learning at their homes during this pandemic only spend an average of 3.6 hours every day compared to the average 7.4-hour learning they spend in school during the normal setting (Grewenig et al., 2020).

Additionally, what further lays down the reasons for students' low academic performance level is that the unprecedented school closures have affected student lives in many profound ways. These include having a higher stressed level, lesser interactions with teachers and peers, the idea of distance learning, lessened motivation towards learning, and unhealthy nutrition (Di Pietro et al., 2020; Schult et al., 2021). Indeed, the fairly satisfactory level of academic achievement in algebra affirms the anticipation of Sintema (2020) that there will most likely be a decrease in students' percentage of passing the math test if the virus is not contained immediately.

\section{Difference in the level of academic achievement in Algebra}

Mann Whitney and Kruskal Wallis were used in Tables 3 and 4 to determine the significant difference in the level of academic achievement in algebra in the new normal when respondents are grouped according to sex and parent's highest educational attainment, respectively. There is no significant difference in the level of academic achievement in algebra in the new normal when respondents are grouped according to sex $[U=7807.0, p=0.061]$, which means that the academic 
achievement level is the same regardless of students' sex. Meanwhile, significance in the mean difference of the respondents is present when they are grouped according to their parent's highest educational attainment $[\mathrm{H}(2)=7.041, \mathrm{p}=0.030]$. This implies that a parent's educational background has a bearing on one's academic achievement level. Dunn's test for Post hoc analysis revealed that students whose parents have college degrees scored significantly higher than other students.

Findings in Table 3 contradict the assumption that boys are perceived to be better performers in math than their counterparts. This is because of the decreasing gender differences, where sex is no longer a significant factor in students' math performance in standardized assessment scales like the regional assessment test (RAT), division achievement test (DAT), and the national achievement test (NAT) due to the varied factors like study habits, mental ability, and students' attitude towards mathematics (Moraña et al., 2017).

This supposition was also consonant with the implications in the study of Odumosu et al. (2018) that academic achievement is not dependent on sex because both males and females have the potential of gaining content knowledge if taught well pedagogically. The results of this study are also consistent with those of Halilić andTinjić (2020). They also found no gender-specific differences in academic achievement during the new normal because students have the intrinsic motivation to succeed regardless of the educational settings.

Table 3. Difference in the Level of Academic Achievement in Algebra of Students according to Sex

\begin{tabular}{lccccc}
\hline \multirow{2}{*}{ Variable } & \multicolumn{2}{c}{ Sex } & \multirow{2}{*}{ U } & $z$ & $p$ \\
\hline \multirow{2}{*}{ Academic achievement } & 13.22 & 14.27 & 7807.000 & -1.877 & 0.030 \\
& $(4.47)$ & $(4.64)$ & & & \\
\hline
\end{tabular}

Note: the difference is significant at $p \leq 0.05$

Table 4. Difference in the Level of Academic Achievement in Algebra of Students according to Parent's Highest Educational Attainment

\begin{tabular}{lcccc}
\hline Parent's Highest Educational Attainment & $\mathrm{M}$ & $\mathrm{H}$ & $\mathrm{df}$ & $\mathrm{P}$ \\
\hline Elementary & 13.30 & & & \\
& $(4.75)$ & & & \\
High School & 13.58 & & & \\
& $(4.26)$ & $7.041^{*}$ & 2 & 0.030 \\
College & 16.09 & & & \\
& $(5.30)$ & & & \\
\hline
\end{tabular}

Note: the difference is significant at $p \leq 0.05$

Meanwhile, according to Liu (2018), the higher the parent's educational level is, the higher the student's academic achievement in algebra. Vowles (2020) suggested that having higher educated parent/s may "buffer" the negative impacts on secondary education transitions to students' academic achievements. Students with elementary/high school level parents have significantly lower academic achievements than those whose parents are college levels because, during the pandemic, parents must assume the full-time responsibility of guiding their children in the learning process. It was revealed that parents who have attained only secondary education or lower do not know how to support their children's learning remotely (Azubuike \& Aina, 2020).

\section{Relationship of between students' sex and parent's highest educational attainment with their level of academic achievement in Algebra}

The Chi-square test of association and Spearman rank correlation in Tables 4 and 5 were used to determine if students' sex and parent's highest educational attainment are significantly related to their level of academic achievement in algebra during the new normal. There is no significant 
relationship between the respondents' sex and their level of academic achievement $\left[\chi^{2}(23)=31.538\right.$, $p=0.110]$ in algebra in the new normal learning, which implies that sex does not have an impact on a student's achievement level; however, significant relationship between the respondents' parents' highest educational attainment and their academic achievement level in algebra $[\rho(268)=0.128$, $p=0.036]$ in the new normal learning is present. This means that the former variable influences the academic achievement level.

Results in Table 5 are supported by the meta-analysis study conducted by Ciftci and Yildiz (2019) because, despite the existing gender stereotypes in mathematics where boys tend to be more dominant in the subject than their counterparts, it is said that boys behave differently than girls in a way that the former read lesser than the latter, are louder, and are aggressive up to the point where the teachers already neglect their lack of understanding of the subject matter (Voyles, 2011).

Meanwhile, Tenenbaum (2018) suggests that parental involvement predicts math scores because parents perceive mathematics learning as a key to their children's future success. Hence, as parents relay the importance of grasping the math subject, students would manifest a positive attitude towards learning the subject (Farr, 2015). This adds to the existing literature affirming that parental involvement profoundly affects learners' academic achievement (Robert, 2021; Assefa \& Sintayehu, 2019).

Table 5. Relationship between Sex and Academic Achievement in Algebra

\begin{tabular}{lccc}
\hline Variable & $\chi^{2}$ & df & $p$ \\
\hline Sex $x$ Academic Achievement & 31.538 & 23 & 0.110 \\
\hline Note: the relationship is significant at $\mathrm{p} \leq 0.05$
\end{tabular}

Table 6. Relationship between Parent's Highest Educational Attainment and Academic Achievement in Algebra

\begin{tabular}{lccc}
\hline Variable & $\rho$ & $\mathrm{df}$ & $\mathrm{p}$ \\
\hline $\begin{array}{l}\text { Parent's educational Achievement x } \\
\text { Academic Achievement }\end{array}$ & $0.128^{*}$ & 268 & 0.036 \\
\hline
\end{tabular}

Note: the relationship is significant at $p \leq 0.05$

Consequently, as parental education increases, their extent of involvement in their child's education also increases (Erol \& Turhan, 2018). Hence, results in Table 5 contribute to the evidence found by Brownstein (2014) that parental education is a significant factor to the extent of students' academic achievement. High school graduate parents would only tend to believe that a college degree is not worth the cost or is no longer needed to pursue one's desired career, and this contradicts the belief of those degree holder parents, who would emphasize academic achievement to be valued and pursued to have a better advantage.

\section{Learning difficulties in Algebra during the new normal}

Table 6 shows that the majority of the students find most difficulty in "transforming quadratic functions into the form " $(n=172)$, followed by "choosing which method (factoring, quadratic formula, extracting square roots, completing the square method) to use in solving quadratic equations" $(n=154)$, and "understanding basic arithmetic when solving $Q E$, like operating integers" $(n=148)$.

Students' difficulty in transforming $a \times 2+d x+c=0$ into $f(x)=a(x-h) 2+k$ coincides with the findings of Parent (2015), who asserted that students prefer the standard form of the quadratic equation more than the standard form the vertex form because the learners generally are not used to dealing with graphs and tables. Results also support the evidence that students may have learned the procedural rules in association with transforming the standard form of QE into vertex form or vice versa; however, they may not understand the implications or the mathematical meanings, causing them to have difficulty in distinguishing the different forms (Graf et al., 2018).

Meanwhile, Makonye and Shingirayi (2014) stressed that learners also have conceptual and procedural errors in factorization and have an incomplete understanding of it. This happens because even if the students are aware of the need to solve for the value of $\mathrm{x}$ in the quadratic equation, they do not know how to factor it with an accurate method basically because of the lack of procedural 
and conceptual knowledge manifested specifically by the errors in algebraic manipulation (Tendere, 2020). Students aged 13-17 struggle with mathematics because of their lack of understanding of the basic concepts like reducing fractions and being thorough in arithmetic, which is a prerequisite for solving equations (Mahanta, 2019). Indeed, students demonstrate slow recall of the basic arithmetic facts and have poorly developed number competencies.

Table 7. Learning Difficulties in Algebra (Quadratic Equation)

\begin{tabular}{lll}
\hline Learning Difficulties & $\mathrm{f}$ & $\%$ \\
\hline Transforming quadratic functions into the form $\mathrm{f}(\mathrm{x})=\left[\mathrm{a}(\mathrm{x}-\mathrm{h})^{\wedge}\right.$ 2] $]+\mathrm{k}$ & 172 & 63.7 \\
Choosing which method to use in solving QE & 154 & 57.0 \\
Understanding basic arithmetic when solving QE, like operating integers & 148 & 54.8 \\
Solving QE through extracting square roots & 145 & 53.7 \\
Characterizing Quadratic Equations & 143 & 53.0 \\
Solving QE through Factoring & 142 & 52.6 \\
Solving QE through the quadratic formula & 139 & 51.5 \\
Solving rational equations transformable into QE & 139 & 51.5 \\
Solving QE through completing the square & 136 & 50.4 \\
Solving word problems involving QE & 134 & 49.6 \\
Characterizing the nature of the roots by using the discriminant & 131 & 48.5 \\
\hline
\end{tabular}

\subsection{Conclusion}

The level of academic achievement of the Grade 9 students at a selected public high school, in general, is low. Since mastery of the basics is a prerequisite to higher mathematical knowledge, the fairly satisfactory (low) performance of the students attests that they have failed to master the needed competencies during their lower grade level although the K-12 curriculum had adapted spiral learning, where key concepts are repeatedly revisited in each level to instill mastery.

However, with a spiral curriculum, learners learn the basics and the additional schemas with deepening layers of complexity. Hence, what had further contributed to the low achievement scores of the students in the first quarter algebra, apart from their non-mastery of the basic concepts, is the idea of distance education during the COVID-19 pandemic, where learners learn only with the aid of their weekly printed modules which their teacher delivers to them. With only a limited source of knowledge and without the guidance of a teacher who is supposed to introduce the learners to the new bunch of concepts, the students can barely grasp the key skills and competencies plotted by the Department of Education.

Based on the findings of the study, it is recommended that algebra teachers take the necessary interventions to address the low level of academic achievement in the first-quarter algebra and the different learning difficulties, which the learners emphasized. They should ensure that the learners have developed their mastery, especially of the basic concepts, so that it would be easy to connect the dots in algebra through interactive and student-centered teaching approaches. If the new normal setting continues, the teacher could use supplemental instructional materials focusing more on the most identified learning difficulties, which he/she could send to the students aside from the weekly modules provided.

Also, school heads should provide further training to their math teachers regarding the trends in teaching/learning mathematics, using effective instructional materials, and minimizing learner differences to become more competent in instilling to the students their expected skills and competencies in algebra.

In addition, parents and/or guardians are encouraged to provide their children with the necessary scaffolding, especially in this new normal set-up. The former may strengthen the learner's intrinsic motivation through constructive feedback, collaboration, empowering their children, and giving them their insights on the importance of learning algebra, being the gateway to higher mathematics.

Finally, future researchers are encouraged to explore the same conditions related to different areas to test the effect of new normal education in learning other subjects in the curriculum. If they wish to stick to mathematics, they may explore students' grit level in learning math amid the pandemic or the effectiveness of school's intervention on students' learning during the new normal. 
They may compare the extent of effectiveness of using printed and online modalities in teaching and learning mathematics or enhance the scope of this study to include the types of schools in the variables to better compare competencies under different conditions.

\section{REFERENCES}

Aggarwal, R., \& Ranganathan, P. (2019). Study designs: Part 2 - Descriptive studies. Perspectives in Clinical Research, 10(1), 34. https://doi.org/10.4103/picr.picr_154_18

Akinlua, S. (2019). Comparing and Contrasting Descriptive Designs: Observational Studies, Correlational Research Developmental Design, and Survey Research. Research gate. https://tinyurl.com/y2v8vvju

Assefa, A., \& Sintayehu, B. (2019). Relationship between parental involvement and students' academic achievement in a model primary and secondary school of Haramaya University, East Hararghe Zone, Oromia Regional State, Ethiopia. International Journal of Education and Literacy Studies, 7(2), 46. https://doi. org/10.7575/aiac.ijels.v.7n.2p.46

Azubuike O. B., \& Aina, B. (2020, August 17). How Parents are Supporting their Children's Learning during the COVID-19 Pandemic in Nigeria. UKFIET. https://www.ukfiet.org/2020/how-parents-are-supporting-theirchildrens-learning-during-the-covid-19-pandemic-in-nigeria/

Bæck, U. K. (2010). Parental involvement practices in formalized home-school cooperation. Scandinavian Journal of Educational Research, 54(6), 549-563. https://doi.org/10.1080/00313831.2010.522845

Brownstein, R. (2014, April 11). Are College Degrees Inherited? Parents' experiences with education strongly influence what their children do after high school. The Atlantic. https://www.theatlantic.com/education/ archive/2014/04/are-college-degrees-inherited/360532/

Cherry, K. (2020). The zone of proximal development as defined by Vygotsky. Verywellmind. https://tinyurl.com/ nm9nmrw3

Chu, F. W. (2010). Women and math performance: The effects of stereotype threat, math identity, and gender identity. ERepository @ Seton Hall. https://scholarship.shu.edu/dissertations/1755/

Ciftci, S. K., \& Yildiz, P. (2019). The effect of gender on algebra achievement: The meta-analysis of trends in international mathematics and science study (TIMSS). Turkish Journal of Computer and Mathematics Education (TURCOMAT), 10(3), 617-627. https://doi.org/10.16949/turkbilmat.568545

Cole, S. A. (2017). The impact of parental involvement on academic achievement. Doctoral dissertation, Northcentral University https://www.proquest.com/openview/654af235fb2228b3d19a3c288f42c822/1?pqorigsite $=$ gscholar $\& \mathrm{cbl}=18750$

Cordova, T., \& Tan, D. (2018). Mathematics proficiency, attitude, and performance of grade 9 students in private high schools in Bukidnon, Philippines. Research Journal of Social Science \& Humanities, 5(2), 102-116. https://tinyurl.com/vk4vd2p

Costa, A., \& Faria, L. (2018). Implicit theories of intelligence and academic achievement: A meta-analytic review. Frontiers in Psychology, 9, 829. https://doi.org/10.3389/fpsyg.2018.00829

Dettmers, S., Yotyodying, S., \& Jonkmann, K. (2019). Antecedents and outcomes of parental homework involvement: How do family-school partnerships affect parental homework involvement and student outcomes? Frontiers in Psychology, 10, 1048. https://doi.org/10.3389/fpsyg.2019.01048

Di Pietro, G., Biagi, F., Dinis Mota Da Costa, P., Karpinski, Z. \& Mazza, J. (2020). The likely impact of COVID-19 on education: Reflections based on the existing literature and recent international datasets. EUR 30275 EN Publications Office of the European Union, Luxembourg. https://doi.org/10.2760/126686

Dorn, E., Hancock, B., Sarakatsannis, J., \& Viruleg, E. (2020). COVID-19 and student learning in the United States: The hurt could last a lifetime. McKinsey \& Company. https://tinyurl.com/2n6d35xn

Erol, Y. C., \& Turhan, M. (2018). The relationship between parental involvement and engagement to school. International Online Journal of Educational Sciences, 10(5), 260-281. https://doi.org/10.15345/ iojes.2018.05.017

Farr, S. (2015). The Role of Parents in Children's Attitudes towards Mathematics. Researchcommons.https:// researchcommons.waikato.ac.nz/bitstream/handle/10289/10007/thesis.pdf?sequence $=3$

Frenzel, M. W. (2008). Reducing gender stereotypes in mathematics. Digital Commons @Brockport. https:// digitalcommons.brockport.edu/ehd_theses/234/

Galindo, E., \& Newton, J. (2017). Synergy at the crossroads: Future directions for theory, research, and practice. Proceedings of the Annual Meeting of the North American Chapter of the International Group for the Psychology of Mathematics Education (39th, Indianapolis, Indiana, October 5-8, 2017). North American Chapter of the International Group for the Psychology of Mathematics Education. https://eric. ed.gov/?id=ED581294

Graf, E. A., Fife, J. H., Howell, H., \& Marquez, E. (2018). The development of a quadratic functions learning progression and associated task shells. ETS Research Report Series, 2018(1), 1-28. https://doi.org/10.1002/ ets2.12234

Grewenig, E., Lergetporer, P., Woessmann, L., \& Zierow, L. (2020). COVID-19 and educational inequality: How school closures affect low- and high-achieving students. CESifo Working Papers, No. 8648. https://www.cesifo.org/ DocDL/cesifo1_wp8648.pdf 
Halilic, M., \& Tinjic, D. (2020). The Impact of Digitalization on Student Academic Performance in Higher Education. https://hj.divaportal.org/smash/get/diva2:1462498/FULLTEXT01.pdf

Heller, K., Finsterwald, M., \& Ziegler, A. (2001). Implicit theories of German mathematics and physics teachers on gender-specific giftedness and motivation. Psychologische Beitrage, 43(1), 172-189.

Jafarov, J. (2015). Factors affecting parental involvement in education: The analysis of literature. Khazar Journal of Humanities and Social Sciences, 18(4), 35-44. https://doi.org/10.5782/2223-2621.2015.18.4.35

Kodippili, A. (2011). Parents' education level in students' mathematics achievement; Do school factors matter? Academic Leadership, 9(1), 1-7. https://scholars.fhsu.edu/cgi/viewcontent.cgi?article=1619\&context=alj

Kuhfeld, M., Soland, J., Tarasawa, B., Johnson, A., Ruzek, E., \& Liu, J. (2020). Projecting the potential impact of COVID-19 school closures on academic achievement. Educational Researcher, 49(8), 549-565. https://doi. org/10.3102/0013189x20965918

Kurt, S. (2020). Vygotsky's zone of proximal development and scaffolding. Educational Technology. https:// educationaltechnology.net/vygotskys-zone-of-proximal-development-and-scaffolding/

Lam, B. T., \& Ducreux, E. (2013). Parental influence and academic achievement among middle school students: Parent perspective. Journal of Human Behavior in the Social Environment, 23(5), 579-590. https://doi.org/10. 1080/10911359.2013.765823

Li, Z., \& Qiu, Z. (2018). How does family background affect children's educational achievement? Evidence from contemporary China. The Journal of Chinese Sociology, 5(1), 1-21. https://doi.org/10.1186/s40711-018-00838

Lim, E. J. (2016). Effectiveness of modular instruction in word problem solving of BEED students. IOSR Journal of Mathematics, 2278-5728. https://doi.org/10.9790/5728-120507596

Liu, X. (2018). The relationship between students' mathematics achievement and social influence: Parental involvement, teacher support, and peer influence. E-Scholarship. https://escholarship.org/uc/item/5q1321p7

Mahanta, P. (2019, October 31). 4 Reasons Why Students Struggle with Math and How to Overcome It. Prodigy Education. https://www.prodigygame.com/main-en/blog/4-reasons-why-students-struggle-with-math-andhow-to-overcome-it/

Majumdar, B. (2020). Report: The impact of COVID-19 on student achievement. Multi Briefs: Exclusive. https:// exclusive.multibriefs.com/content/report-the-impact-of-covid-19-on-student-achievement/education

Makonye, J., \& Shingirayi, M. (2014). The obstacles faced by the learners in the learning of quadratic inequalities. Mediterranean Journal of Social Sciences, 716-725. https://doi.org/10.5901/mjss.2014.v5n27p716

Malindog-Uy, A. (2020). COVID-19 impact on mental health of Filipinos. The ASEAN Post. https://theaseanpost. com/article/covid-19-impact-mental-health-filipinos

Maloney, E. A., Schaeffer, M. W., \& Beilock, S. L. (2013). Mathematics anxiety and stereotype threat: Shared mechanisms, negative consequences, and promising interventions. Research in Mathematics Education, 15(2), 115-128. https://doi.org/10.1080/14794802.2013.797744

Mateo, J. (2020). Written works, performance tasks: Here's how students will be graded this school year. OneNews. Ph. https://www.onenews.ph/written-works-performance-tasks-here-s-how-students-will-be-graded-thisschool-year

McElroy, M. (2011). Gender stereotypes about math develop as early as second grade. UW News. https://www. washington.edu/news/2011/03/14/gender-stereotypes-about-math-develop-as-early-as-second-grade/

Mittelberg, D., Rozner, O., \& Forgasz, H. (2011). Mathematics and gender stereotypes in one Jewish and one Druze grade 5 classroom in Israel. Education Research International, 2011, 1-10. https://doi. org/10.1155/2011/545010

Moraña, M., Edaño, D., \& Punzalan, E. M. (2017). Achievement test and academic performance in mathematics of second-year high school students in the Division of Zambales, Philippines. International Journal of Development Research, 7(1), 11272-11277.

Morrissey, K., Hallett, D., Bakhtiar, A., \& Fitzpatrick, C. (2019). Implicit math-gender stereotypes present in adults but not in 8th grade. Journal of Adolescence, 74, 173-182. https://doi.org/10.1016/j.adolescence.2019.06.003

Mulwa, E. (2015). Difficulties encountered by students in the learning and usage of mathematical terminology: A critical literature review. Journal of Education and Practice, 6(13), 27-37. ERIC. https://eric. ed.gov/?id=EJ1080447

Ntekane, A. (2018). Parental involvement in education. ResearchGate, 1-5. https://doi.org/10.13140/ RG.2.2.36330.21440

Odumosu, M. O., Olisama, O. V., \& Areelu, F. (2018). Teachers' content and pedagogical knowledge on students' achievement in algebra. International Journal of Education and Research, 6(3), 83-94. https://www.ijern.com/ journal/2018/March-2018/11.pdf

Parent, J. S. S. (2015). Students' understanding of quadratic functions: Learning from students' voices. ScholarWorks @ UVM. https://tinyurl.com/nkmnyxn2

Pramesti, T. I., \& Retnawati, H. (2019). Difficulties in learning algebra: An analysis of students' errors. Journal of Physics: Conference Series, 1320, 1-7. https://doi.org/10.1088/1742-6596/1320/1/012061

Reyes-Chua, E., Sibbaluca, B. G., Miranda, R. D., Palmario, G. B., Moreno, R. P., \& Solon, J. P. T. (2020). The status of the implementation of the e-learning classroom in selected higher education institutions in region IV-A amidst the COVID-19 crisis. Journal of Critical Reviews, 7(11), 253-258. https://doi.org/10.31838/jcr.07.11.41 
Robert, S. (2021). The relationship between parental involvement and mathematics achievement in struggling mathematics learners. Applied Psychology Opus. https://wp.nyu.edu/steinhardt-appsych_opus/therelationship-between-parental-involvement-and-mathematics-achievement-in-struggling-mathematicslearners/

Sawchuk, S. S. S. D. (2021). Kids are behind in math because of COVID-19. Here's what research says could help. Education Week. https://www.edweek.org/teaching-learning/kids-are-behind-in-math-because-of-covid19-heres-what-research-says-could-help/2020/12

Schaffhauser, D. (2020). COVID learning loss in math hits hard in grades 4-8. The Journal. https://thejournal.com/ articles/2020/11/30/covid-learning-loss-in-math-hits-hard-in-grades-4-8.aspx

Schult, J., Mahler, N., Fauth, B., \& Lindner, M. (2021). Did Students Learn Less During the COVID-19 Pandemic? Reading and Mathematics Competencies Before and After the First Pandemic Wave. PsyArXiv Preprints. https://psyarxiv.com/pqtgf/

Shafer, S. (2020). Teaching and learning in the pandemic. Education Week. https://www.edweek.org/teaching learning/teaching-and-learning-in-the-pandemic/2020/08

Silk, C. J. G., Silk, B. B. G., \& Somblingo, R. A. (2017). Modular approach in teaching problem solving: A metacognitive process. International Journal of Science and Research (IJSR), 6(8), 670-677. https://doi. org/10.21275/ART20175782

Sintema, E. J. (2020). Effect of COVID-19 on the performance of grade 12 students: Implications for STEM education. Eurasia Journal of Mathematics, Science and Technology Education, 16(7), 1-6. https://doi. org/10.29333/ejmste/7893

Tabaeian, M. (2016). The effect of parental over-involvement on educational attainment. Proceedings of the 1st national English language conference. ResearchGate. https://www.researchgate.net/publication/308611703_ The_Effect_of_Parental_Over-involvement_on_Educational_Attainment

Tekin, A. K. (2011). Parent involvement revisited: Background, theories, and models. IJAES, 11(1), 1-13. https:// www.researchgate.net/publication/268079028_Parent_Involvement_Revisited_Background_Theories_and_ Models

Tendere, J. (2020). An analysis of errors and misconceptions in the study of quadratic equations. European Journal of Mathematics and Science Education, 1(2), 81-90. https://doi.org/10.12973/ejmse.1.2.81

Tenenbaum, J.L. (2018). The relationship between parent-school involvement and math achievement in economically at-risk students. OhioLINK. https://etd.ohiolink.edu/apexprod/rws_olink/r/1501/10?clear=10\&p10_ accession_num =miami1529675587893696

Teodoro, L. (2020). Philippine education in crisis. BusinessWorld. https://www.bworldonline.com/philippineeducation-in-crisis/

Terada, Y. (2020). Covid-19's impact on students' academic and mental well-being. Edutopia. https://tinyurl. com/4p8ts259

Vijayakumaran, R. (2017). Minimizing gender stereotype threat for female students in the math classroom. http:// hdl.handle.net/1807/77240

Vowles, N. (2020, May 20). Parents with degrees give their children a significant advantage in math. ScienceDaily. https://www.sciencedaily.com/releases/2020/05/200520124924.htm

Voyles, M. J. (2011). Student academic success as related to student age and gender. https://core.ac.uk/download/ pdf/51197011.pdf

Willens, M. (2013). Ninth grade: The most important year in high school. The Atlantic. https://www.theatlantic. com/education/archive/2013/11/ninth-grade-the-most-important-year-in-high-school/281056/

\section{Correspondence:}

DIANA B. RODRIGO*

Dianarodrigo19@gmail.com

https://orcid.org/0000-0001-7856-0479

ALFREDO D. ALAVE

alfredo_alave@yahoo.com

https://orcid.org/0000-0002-3355-4865

*Principal Correspondent 